\title{
ERRATUM
}

Genes \& Development 31: 537-552 (2017)

\section{Erratum: BRaf signaling principles unveiled by large-scale human mutation analysis with a rapid lentivirus-based gene replacement method}

Chae-Seok Lim, Xi Kang, Vincent Mirabella, Huaye Zhang, Qian Bu, Yoichi Araki, Elizabeth T. Hoang, Shiqiang Wang, Ying Shen, Sukwoo Choi, Bong-Kiun Kaang, Qiang Chang, Zhiping P. Pang, Richard L. Huganir, and J. Julius Zhu

In the above-mentioned article, the abstract and first paragraph contained two typographical errors that have been corrected in both the PDF and full-text HTML files online. The phrase "small GTPase" was deleted, and "gene mutation-cell behavior" should read "gene-mutation-cell-behavior." The errors have been corrected in both the PDF and full-text HTML files online.

doi: 10.1101/gad.300863.117 


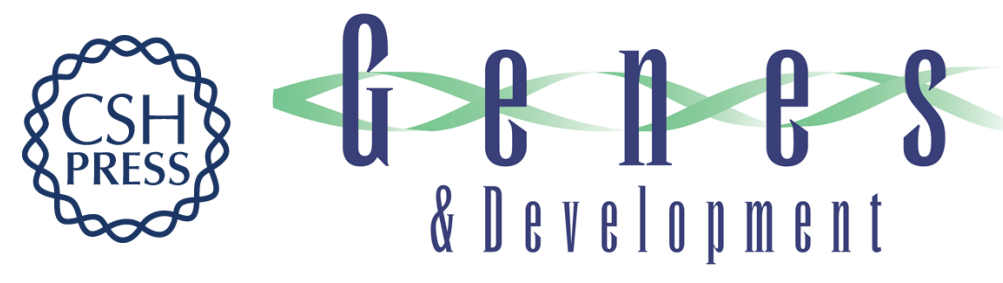

\section{Erratum: BRaf signaling principles unveiled by large-scale human mutation analysis with a rapid lentivirus-based gene replacement method}

Chae-Seok Lim, Xi Kang, Vincent Mirabella, et al.

Genes Dev. 2017, 31:

Access the most recent version at doi:10.1101/gad.300863.117

Related Content BRaf signaling principles unveiled by large-scale human mutation analysis with a rapid lentivirus-based gene replacement method

Chae-Seok Lim, Xi Kang, Vincent Mirabella, et al.

Genes Dev. March , 2017 31: 537-552

\section{License}

Email Alerting

Receive free email alerts when new articles cite this article - sign up in the box at the top

Service

right corner of the article or click here.

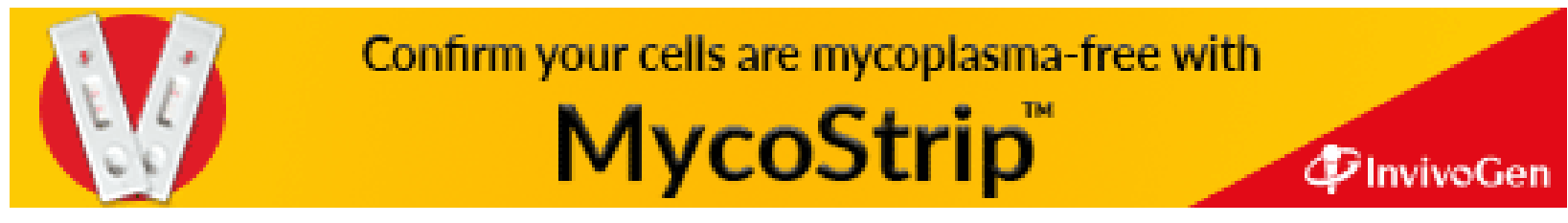

